\title{
PREVALENCE AND SOCIO-DEMOGRAPHIC CORRELATES OF DAILY CIGARETTE SMOKING IN POLAND: RESULTS FROM THE GLOBAL ADULT TOBACCO SURVEY (2009-2010)
}

\section{DOROTA KALETA ${ }^{1}$, TERESA MAKOWIEC-DĄBROWSKA ${ }^{2,3}$, ELŻBIETA DZIANKOWSKA-ZABORSZCZYK ${ }^{1}$, and ADAM FRONCZAK ${ }^{4}$}

\author{
${ }^{1}$ Medical University of Łódź, Łódź, Poland \\ Department of Preventive Medicine \\ ${ }^{2}$ Nofer Institute of Occupational Medicine, Łódź, Poland \\ Department of Work Physiology and Ergonomics \\ ${ }^{3}$ Medical University of Łódź, Łódź, Poland \\ Public Health Faculty \\ ${ }^{4}$ Ministry of Health, Warszawa, Poland
}

\begin{abstract}
Objectives: The aim of the study was to evaluate the prevalence and socio-demographic correlates of daily cigarette smoking among adults in Poland. Materials and Methods: A nationally representative household study was implemented between 2009 and 2010 to explore smoking pattern among the population aged 15 years and older. The smoking status and socio-demographic data were determined based on the Global Adult Tobacco Survey (GATS) questionnaire. Out of the 14000 households selected for the survey, 7840 sampled persons completed the interviews, including 2162 respondents who declared daily smoking of cigarettes. Logistic regression models were applied to assess factors related to daily cigarette smoking. Results: Over 33\% of men and $21 \%$ of women $(\mathrm{p}<0.01)$ reported tobacco smoking on a daily basis. The significantly higher risk of smoking on a daily basis was observed among the male and female 20-59 years of age compared to the 60 or older population $(\mathrm{p}<0.05)$. For men and women with the lower educational (primary/vocational/secondary) level, the risk of smoking was significantly higher than for the subjects with university degree $(\mathrm{p}<0.05)$. The unemployed men smoked daily significantly more frequently than the employed ones (OR $=1.8 ; 95 \%$ CI: 1.4-2.4). This association was not observed among women $(\mathrm{p}>0.05)$. The residents of urban areas smoked significantly more frequently than people living in rural settings $(\mathrm{p}<0.05)$. Conclusions: Actions to tackle socio-economic inequalities in smoking need to be intensified. The antismoking efforts should be focused on the population of Poles at large and people with lower educational levels, unemployed men, and residents of large urban settings in particular. The tobacco control interventions should also address the population of women at reproductive age.
\end{abstract}

Key words:

Tobacco smoking, Socio-demographic factors, Adults, GATS, Poland

Financial support was provided by the Bloomberg Initiative to Reduce Tobacco Use, a program of Bloomberg Philanthropies.

Received: October 27, 2011. Accepted: January 23, 2012.

Address reprint request to D. Kaleta, Department of Preventive Medicine, Medical University of Łódź, Żeligowskiego 7/9, 90-752 Łódź, Poland (e-mail: dkaleta@op.pl). 


\section{INTRODUCTION}

Monitoring of tobacco consumption is crucial for tobacco control policies in terms of identifying specific risk groups as well as risk factors. Additionally, monitoring on regular basis allows for the evaluation of effective tobacco control activities. Although there are a lot of surveys conducted all over the world, their results are not always comparable between the countries or even within the country due to different methodologies and qualities of data [1-3]. National epidemiological surveillance of tobacco use is being conducted in our country. However, surveillance data produced in Poland is generally not comparable across studies or time [4,5]. Utilization of such data on tobacco use by government and policy makers is severely limited. Therefore, the inclusion of Poland into the Global Tobacco Surveillance System and the implementation of Global Adult Tobacco Survey (GATS) was an important step towards obtaining recent data on the tobacco epidemic in our country, providing reliable and comparable information.

The aim of the study was to evaluate the prevalence and socio-demographic correlates of daily cigarette smoking among adults in Poland.

\section{MATERIALS AND METHODS}

\section{Study design and sample}

Global Adult Tobacco Survey is one of the Global Tobacco Surveillance System (GTSS) components [6-8]. Global Adult Tobacco Survey is a representative, national survey of households, standardized on a global scale.

In Poland, the Ministry of Health $(\mathrm{MoH})$ coordinated and supervised implementation process of the study. Scientific and technical coordination of the study was carried out by two committees appointed by the MoH: the GATS Poland Scientific Committee and the GATS Poland Steering Committee. The Ministry of Health revised and approved the study questionnaire and protocol [9]. GATS Poland team was supported by experts from the World Health Organization and the Centers for Disease Control and Prevention.

A sample of 14000 households was randomly selected via a three-stage stratified cluster sample of non-institutional population aged 15 years and older including men and women. The selection was based on the data obtained from the Central Statistical Office. The GATS Poland sample design provides cross-sectional estimates for the country as a whole, as well as estimates by the degree of urbanization and gender.

\section{Questionnaire design}

GATS questionnaire consisted of household and individual questionnaire and allowed to obtain a broad range of data on tobacco consumption and related issues. The household questionnaire covered questions concerning all adult residents in order to randomly select an eligible respondent to complete the individual questionnaire. The individual questionnaire consisted of nine sections including background characteristics of respondents, information about tobacco smoking, smokeless tobacco use, cessation, secondhand smoke and other important aspects related to tobacco use.

In Poland, the standard GATS questionnaire was used, adjusted by experts to match the national context [9]. The English version of the GATS questionnaire was translated into Polish and then back translated to ensure consistency. In February 2009, a pretest was conducted among 200 residents of the Mazowieckie Province to verify and eventually improve the adapted version of the GATS questionnaire, as well as all technical aspects of the survey and the operation of IT equipment. The GATS study made use of electronic means of data collection for both the household and individual questionnaire. Interviewers were equipped with handheld computers.

Finally, the GATS fieldwork was undertaken between November 2009 and March 2010. Questionnaires were 
administrated at respondents' homes during face-toface interviews. To assure safety of interviewers and effective fieldwork, special introductory letters advising of the study purpose signed by the Minister of Health were sent to all sampled addresses. Fieldwork supervisors conducted repeated inspections in selected samples of interviewers. Multi stage data quality control was also applied in order to assure the highest quality of standards.

\section{Study variables}

Information on smoking of tobacco products, including cigarette smoking, was obtained from the questionnaire and divided into specific groups. For the purpose of performed analysis we focused on data regarding daily cigarette smoking (manufactured and/or hand-rolled). A daily smoker was defined as a person who smokes regularly, at least 1 manufactured and/or hand-rolled cigarette a day.

Educational level was categorized as: primary education - including no formal education, incomplete elementary, elementary, and junior high school; vocational education - including only vocational schooling; secondary education - including secondary (high school, technical college), and junior college; and finally higher education - included Bachelor's Degree, or higher. For the occupational classification, we distinguished several groups: hired employee (employed in a company, enterprise-based on employment contract or contract), selfemployed (owner or co-owner of a company or helping spouse), farmer (person keeping his/her own farm, owner or co-owner of farm or helping spouse), student and pupil, person occupied with household keeping (raising children, homemaker), pensioner, unemployed (currently with no permanent job). Place of residence was characterized depending on the size of the population living there, including rural area, urban area up to 50000 , from 50000 to 200000 , and over 200000 inhabitants.

\section{Statistical analyses}

To compare the frequency and assess statistical significance of the given categories of quantitative characteristics in the analyzed groups, the chi-square test was implemented. All analyses were performed separately for men and women for 6 age (in full years) groups: 15-19, 20-29, 30-39, 40-49, 50-59, 60 years and older. In order to identify factors that could contribute to daily smoking, the logistic regression analysis was performed. In the first stage crude coefficients - odds ratios (OR) of the impact of odd variables on the daily smoking in males and females were calculated. This was followed by a multifactorial analysis considering the simultaneous effect of all variables on the risk of smoking. All $p$ values were two-sided and $p<0.05$ was set as statistically significant. The statistical analysis was performed using the STATISTICA Windows XP version 8.0 software.

\section{RESULTS}

\section{Participation rate and smoking prevalence}

Out of the 14000 households selected for the survey, 8948 (63.9\%) households and 7840 (93.9\%) sampled persons successfully completed the interviews. The total survey response rate was $65.1 \%$. Among the 3867 male respondents, $3 \%(\mathrm{n}=116)$ were occasional tobacco smokers, former tobacco smokers were $28.7 \%(\mathrm{n}=1108)$ and never smokers were $34.5 \%(n=1334)$. Among 3973 female respondents occasional, former and never smokers were $3.1 \%(\mathrm{n}=121) ; 16.1 \%(\mathrm{n}=644)$; and $58.9 \%$ $(\mathrm{n}=2338)$, respectively. Significantly greater number of men, $33.9 \%(n=1309)$ compared to women, $21.9 \%$ $(\mathrm{n}=870)(\mathrm{p}<0.01)$ reported smoking tobacco products on a daily basis. In this group, only four men and one women smoked daily tobacco products other than manufactured and/or hand-rolled cigarettes. We additionally excluded from the analysis all records with missing data. Finally, 2162 respondents including 864 women and 1298 men reported daily cigarette smoking. Characteristics of the study sample are displayed in Tables 1 and 2. 
Table 1. Odds ratios (OR) and 95\% confidence intervals (CI) for daily cigarette smoking by selected variables in men (N = 1298). Results from the Global Adult Tobacco Survey Poland (2009-2010)

\begin{tabular}{|c|c|c|c|c|c|c|c|}
\hline \multirow[b]{2}{*}{ Variables } & \multirow{2}{*}{$\begin{array}{c}\text { Daily cigarette smoking } \\
\mathrm{n}(\%) \\
(95 \% \mathrm{CI})\end{array}$} & \multicolumn{2}{|c|}{ Univariate analysis } & \multirow[b]{2}{*}{ p-value } & \multicolumn{2}{|c|}{ Multivariate analysis } & \multirow[b]{2}{*}{ p-value } \\
\hline & & OR & $95 \% \mathrm{CI}$ & & OR & $95 \% \mathrm{CI}$ & \\
\hline \multicolumn{8}{|l|}{ Age (years) } \\
\hline $15-19$ & $\begin{array}{c}31(17.1) \\
(11.6-22.6)\end{array}$ & 0.80 & $0.52-1.22$ & $>0.05$ & 1.05 & $0.56-1.96$ & $>0.05$ \\
\hline $20-29$ & $\begin{array}{c}223(33.4) \\
(29.8-37.0)\end{array}$ & 1.94 & $1.54-2.45$ & 0.0001 & 1.79 & $1.24-2.60$ & 0.001 \\
\hline $30-39$ & $\begin{array}{c}289(37.7) \\
(34.3-41.1)\end{array}$ & 2.34 & $1.87-2.93$ & 0.0001 & 1.85 & $1.29-2.64$ & 0.001 \\
\hline $40-49$ & $\begin{array}{c}307(44.4) \\
(40.7-48.1)\end{array}$ & 3.09 & $2.46-3.87$ & 0.0001 & 2.16 & $1.52-3.06$ & 0.0001 \\
\hline $50-59$ & $\begin{array}{c}279(40.1) \\
(36.5-43.7)\end{array}$ & 2.59 & $2.06-3.25$ & 0.0001 & 1.76 & $1.29-2.47$ & 0.001 \\
\hline$>60$ & $\begin{array}{c}169(20.5) \\
(17.7-23.3)\end{array}$ & 1 & reference & & 1 & reference & \\
\hline \multicolumn{8}{|l|}{ Education } \\
\hline primary & $\begin{array}{c}213(29.6) \\
(26.3-32.9)\end{array}$ & 1.47 & $1.13-1.93$ & 0.01 & 2.86 & $2.10-3.91$ & 0.0001 \\
\hline vocational & $\begin{array}{c}546(43.9) \\
(41.1-46.7)\end{array}$ & 2.75 & $2.16-3.50$ & 0.0001 & 3.00 & $2.32-3.89$ & 0.0001 \\
\hline secondary & $\begin{array}{l}431(31.3) \\
(28.9-33.7)\end{array}$ & 1.60 & $1.25-2.04$ & 0.0001 & 1.72 & $1.34-2.21$ & 0.0001 \\
\hline high & $\begin{array}{c}10(22.2) \\
(10.1-34.3)\end{array}$ & 1 & reference & & 1 & reference & \\
\hline \multicolumn{8}{|l|}{ Occupational classification } \\
\hline $\begin{array}{l}\text { hired employee, employed in } \\
\text { a company, enterprise-based on } \\
\text { employment contract or contract }\end{array}$ & $\begin{array}{c}645(38.3) \\
(36.0-40.6)\end{array}$ & 1 & reference & & 1 & reference & \\
\hline $\begin{array}{l}\text { self-employed, owner } \\
\text { or co-owner of a company } \\
\text { or helping spouse }\end{array}$ & $\begin{array}{c}113(34.7) \\
(29.5-39.9)\end{array}$ & 0.86 & $0.67-1.09$ & $>0.05$ & 0.91 & $0.70-1.17$ & $>0.05$ \\
\hline $\begin{array}{l}\text { farmer person keeping his/her } \\
\text { own farm, owner or co-owner } \\
\text { of farm or helping spouse }\end{array}$ & $\begin{array}{c}79(33.3) \\
(27.3-39.3)\end{array}$ & 0.80 & $0.60-1.07$ & $>0.05$ & 0.72 & $0.53-0.98$ & $<0.05$ \\
\hline student, pupil & $\begin{array}{c}44(15.8) \\
(11.5-20.1)\end{array}$ & 0.30 & $0.21-0.42$ & 0.0001 & 0.39 & $0.25-0.62$ & 0.0001 \\
\hline $\begin{array}{l}\text { person occupied with household } \\
\text { keeping, raising children, } \\
\text { homemaker }\end{array}$ & $\begin{array}{c}15(50.0) \\
(32.1-67.9)\end{array}$ & 1.61 & $0.78-3.31$ & $>0.05$ & 1.57 & $0.75-3.29$ & $>0.05$ \\
\hline
\end{tabular}


Table 1. Odds ratios (OR) and 95\% confidence intervals (CI) for daily cigarette smoking by selected variables in men $(\mathrm{N}=1298)$. Results from the Global Adult Tobacco Survey Poland (2009-2010) - cont.

\begin{tabular}{|c|c|c|c|c|c|c|c|}
\hline \multirow[b]{2}{*}{ Variables } & \multirow{2}{*}{$\begin{array}{c}\text { Daily cigarette smoking } \\
\mathrm{n}(\%) \\
(95 \% \mathrm{CI})\end{array}$} & \multicolumn{2}{|c|}{ Univariate analysis } & \multirow[b]{2}{*}{ p-value } & \multicolumn{2}{|c|}{ Multivariate analysis } & \multirow[b]{2}{*}{$\mathrm{p}$-value } \\
\hline & & OR & $95 \% \mathrm{CI}$ & & OR & $95 \% \mathrm{CI}$ & \\
\hline retired person & $\begin{array}{c}149(19.6) \\
(16.8-22.4)\end{array}$ & 0.39 & $0.32-0.48$ & 0.0001 & 0.55 & $0.39-0.78$ & 0.001 \\
\hline pensioner due to disability & $\begin{array}{l}117(42.9) \\
(37.0-48.8)\end{array}$ & 1.21 & $0.93-1.56$ & $>0.05$ & 1.15 & $0.86-1.55$ & $>0.05$ \\
\hline $\begin{array}{l}\text { unemployed, currently with no } \\
\text { permanent job }\end{array}$ & $\begin{array}{l}136(57.4) \\
(51.1-63.7)\end{array}$ & 2.16 & $1.64-2.85$ & 0.0001 & 1.83 & $1.37-2.43$ & 0.0001 \\
\hline \multicolumn{8}{|l|}{ Place of residence } \\
\hline rural & $\begin{array}{l}662(32.5) \\
(30.5-34.5)\end{array}$ & 1 & reference & & 1 & reference & \\
\hline \multicolumn{8}{|l|}{ urban - habitants (n) } \\
\hline$<50000$ & $\begin{array}{l}233(34.0) \\
(30.5-37.5)\end{array}$ & 1.07 & $0.89-1.29$ & $>0.05$ & 1.13 & $0.93-1.37$ & $>0.05$ \\
\hline 50 000-200000 & $\begin{array}{l}174(39.8) \\
(35.2-44.4)\end{array}$ & 1.38 & $1.12-1.71$ & 0.001 & 1.57 & $1.24-1.97$ & 0.001 \\
\hline$>200000$ & $\begin{array}{l}229(34.0) \\
(30.4-37.6)\end{array}$ & 1.07 & $0.89-1.28$ & $>0.05$ & 1.27 & $1.04-1.56$ & 0.01 \\
\hline
\end{tabular}

Table 2. Odds ratios (OR) and 95\% confidence intervals (CI) for daily cigarette smoking by selected variables in women $(\mathrm{N}=864)$. Results from the Global Adult Tobacco Survey Poland (2009-2010)

\begin{tabular}{|c|c|c|c|c|c|c|c|}
\hline \multirow[b]{2}{*}{ Variables } & \multirow{2}{*}{$\begin{array}{c}\text { Daily cigarette smoking } \\
\mathrm{n}(\%) \\
(95 \% \mathrm{CI})\end{array}$} & \multicolumn{2}{|c|}{ Univariate analysis } & \multirow[b]{2}{*}{ p-value } & \multicolumn{2}{|c|}{ Multivariate analysis } & \multirow[b]{2}{*}{$\mathrm{p}$-value } \\
\hline & & OR & $95 \% \mathrm{CI}$ & & OR & $95 \% \mathrm{CI}$ & \\
\hline \multicolumn{8}{|l|}{ Age (years) } \\
\hline $15-19$ & $\begin{array}{c}12(6.8) \\
(3.1-10.5)\end{array}$ & 0.77 & $0.41-1.43$ & $>0.05$ & 1.17 & $0.48-2.83$ & $>0.05$ \\
\hline $20-29$ & $\begin{array}{c}142(22.8) \\
(19.5-26.1)\end{array}$ & 3.09 & $2.32-4.11$ & 0.0001 & 2.27 & $1.47-3.50$ & 0.001 \\
\hline $30-39$ & $\begin{array}{c}164(22.2) \\
(19.2-25.2)\end{array}$ & 2.99 & $2.27-3.95$ & 0.0001 & 1.81 & $1.19-2.56$ & 0.01 \\
\hline $40-49$ & $\begin{array}{c}215(33.4) \\
(29.8-37.0)\end{array}$ & 5.13 & $3.93-6.69$ & 0.0001 & 3.12 & $2.08-4.70$ & 0.0001 \\
\hline $50-59$ & $\begin{array}{l}241(32.9) \\
(7.0-10.4)\end{array}$ & 5.10 & $3.92-6.65$ & 0.0001 & 3.38 & $2.38-4.80$ & 0.0001 \\
\hline$>60$ & $\begin{array}{c}90(8.7) \\
(7.0-10.4)\end{array}$ & 1 & reference & & 1 & reference & \\
\hline
\end{tabular}


Table 2. Odds ratios (OR) and 95\% confidence intervals (CI) for daily cigarette smoking by selected variables in women $(\mathrm{N}=864)$. Results from the Global Adult Tobacco Survey Poland (2009-2010) - cont.

\begin{tabular}{|c|c|c|c|c|c|c|c|}
\hline \multirow[b]{2}{*}{ Variables } & \multirow{2}{*}{$\begin{array}{c}\text { Daily cigarette smoking } \\
\mathrm{n}(\%) \\
(95 \% \mathrm{CI})\end{array}$} & \multicolumn{2}{|c|}{ Univariate analysis } & \multirow[b]{2}{*}{ p-value } & \multicolumn{2}{|c|}{ Multivariate analysis } & \multirow[b]{2}{*}{$\mathrm{p}$-value } \\
\hline & & OR & $95 \% \mathrm{CI}$ & & OR & $95 \% \mathrm{CI}$ & \\
\hline \multicolumn{8}{|l|}{ Education } \\
\hline primary & $\begin{array}{c}119(13.1) \\
(10.9-15.3)\end{array}$ & 0.65 & $0.49-0.85$ & 0.01 & 1.72 & $1.23-2.41$ & 0.01 \\
\hline vocational & $\begin{array}{l}243(29.0) \\
(25.9-32.1)\end{array}$ & 1.74 & $1.36-2.23$ & 0.0001 & 2.27 & $1.72-3.01$ & 0.0001 \\
\hline secondary & $\begin{array}{l}380(24.4) \\
(22.3-26.5)\end{array}$ & 1.38 & $1.10-1.73$ & 0.01 & 1.64 & $1.29-2.09$ & 0.0001 \\
\hline high & $\begin{array}{l}122(18.9) \\
(15.9-21.9)\end{array}$ & 1 & reference & & 1 & reference & \\
\hline \multicolumn{8}{|l|}{ Occupational classification } \\
\hline $\begin{array}{l}\text { hired employee, employed in } \\
\text { a company, enterprise-based on } \\
\text { employment contract or contract }\end{array}$ & $\begin{array}{c}391(29.3) \\
(26.9-31.7)\end{array}$ & 1 & reference & & 1 & reference & \\
\hline $\begin{array}{l}\text { self-employed, owner or co- } \\
\text { owner of a company or helping } \\
\text { spouse }\end{array}$ & $\begin{array}{c}49(28.5) \\
(21.8-35.2)\end{array}$ & 0.96 & $0.68-1.37$ & $>0.05$ & 0.99 & $0.69-1.42$ & $>0.05$ \\
\hline $\begin{array}{l}\text { farmer person keeping his/her } \\
\text { own farm, owner or co-owner of } \\
\text { farm or helping spouse }\end{array}$ & $\begin{array}{c}28(18.4) \\
(12.2-24.6)\end{array}$ & 0.54 & $0.36-0.84$ & 0.01 & 0.55 & $0.35-0.87$ & 0.01 \\
\hline student, pupil & $\begin{array}{c}23(8.1) \\
(4.9-11.3)\end{array}$ & 0.21 & $0.14-0.33$ & 0.0001 & 0.34 & $0.19-0.62$ & 0.0001 \\
\hline $\begin{array}{l}\text { person occupied with household } \\
\text { keeping, raising children, } \\
\text { homemaker }\end{array}$ & $\begin{array}{c}142(28.6) \\
(24.6-32.6)\end{array}$ & 0.97 & $0.77-1.22$ & $>0.05$ & 0.97 & $0.76-1.24$ & $>0.05$ \\
\hline retired person & $\begin{array}{l}119(10.7) \\
(8.9-12.5)\end{array}$ & 0.29 & $0.23-0.36$ & 0.0001 & 0.52 & $0.36-0.73$ & 0.0001 \\
\hline pensioner due to disability & $\begin{array}{c}57(27.9) \\
(21.7-34.1)\end{array}$ & 0.94 & $0.68-1.30$ & $>0.05$ & 0.89 & $0.62-1.29$ & $>0.05$ \\
\hline $\begin{array}{l}\text { unemployed, currently with no } \\
\text { permanent job }\end{array}$ & $\begin{array}{l}55(28.2) \\
(21.9-34.5)\end{array}$ & 0.95 & $0.68-1.33$ & $>0.05$ & 0.96 & $0.68-1.37$ & $>0.05$ \\
\hline \multicolumn{8}{|l|}{ Place of residence } \\
\hline rural & $\begin{array}{c}349(17.9) \\
(10.4-25.4)\end{array}$ & 1 & reference & & 1 & reference & \\
\hline \multicolumn{8}{|l|}{ urban - habitants (n) } \\
\hline$<50000$ & $\begin{array}{c}154(20.7) \\
(17.8-23.6)\end{array}$ & 1.19 & $0.97-1.70$ & $>0.05$ & 1.19 & $0.95-1.50$ & $>0.05$ \\
\hline $50000-200000$ & $\begin{array}{l}152(28.0) \\
(24.2-31.8)\end{array}$ & 1.78 & $1.43-2.22$ & 0.0001 & 1.79 & $1.41-2.27$ & 0.0001 \\
\hline$>200000$ & $\begin{array}{l}209(29.1) \\
(25.8-32.4)\end{array}$ & 1.88 & $1.54-2.89$ & 0.0001 & 1.92 & $1.54-2.39$ & 0.0001 \\
\hline
\end{tabular}




\section{Univariate analysis}

The results of the logistic regression analysis are presented in Tables 1 and 2. The daily smoking rate was higher among the subjects above 19 years of age compared to those aged 60 years or older for both men and women $(\mathrm{p}<0.0001)$. The higher percentages of smokers were observed among the people between 40 and 59 years of age (more than $40 \%$ among men and more than $32 \%$ among women). Among the male population, the risk of smoking was over 3 times higher in the age category 40-49 compared to the people older than $60(\mathrm{OR}=3.1 ; 95 \% \mathrm{CI}: 2.5-3.9)$. For the women, such risk was even higher $(\mathrm{OR}=5.1 ; 95 \%$ CI: 3.9-6.7). Moreover, low education as well as urban residence was positively associated with daily cigarette smoking for both genders. The daily smoking rate was higher among males reporting lower educational levels (vocational/secondary) than among males with higher education (primary: OR $=1.5 ; 95 \%$ CI: 1.1-1.9; vocational: $\mathrm{OR}=2.7 ; 95 \% \mathrm{CI}: 2.2-3.5 ;$ secondary: $\mathrm{OR}=1.6 ; 95 \% \mathrm{CI}: 1.2-2.0)$. The same association was observed for the female subjects (vocational: $\mathrm{OR}=1.7 ; 95 \% \mathrm{CI}: 1.4-2.2$; and secondary: $\mathrm{OR}=1.4 ; 95 \% \mathrm{CI}$ : 1.1-1.7). In men, unemployment was a significant determinant of smoking $(\mathrm{OR}=2.2 ; 95 \% \mathrm{CI}: 1.6-2.8)$, while among women smoking was not correlated to employment status ( $p>0.05)$.

\section{Multivariate analysis}

The multivariate analysis confirmed the results observed in the univariate section. The significantly higher risk of smoking on a daily basis was observed among the people 20-59 years of age compared to the 60 or older population $(\mathrm{p}<0.05)$. This association was noted among both gender groups. For men and women with the lower educational level (primary/vocational/secondary), the risk of smoking was significantly higher than in the subjects with university degree $(p<0.05)$. The unemployed men smoked daily significantly more frequently than the employed ones $(\mathrm{OR}=1.8 ; 95 \% \mathrm{CI}$ : $1.4-2.4)$. This association was not observed among women $(\mathrm{p}>0.05)$. The residents of urban areas smoked significantly more frequently than people living in rural settings $(\mathrm{p}<0.05)$.

\section{DISCUSSION}

Despite the health consequences of active and passive smoking and action taken on international and local level to decrease the percentages of smokers, the results of our study indicated that still about $34 \%$ of men and $22 \%$ of women smoked cigarettes on a daily basis $(\mathrm{p}<0.01)$. Almost the same percentage of daily smokers was observed in Hungary (39\% men and 28\% women) [10]. The current smoking status reported by higher number of men compared to women is observed in most European countries. The largest proportions of male smokers were recorded in Ukraine (62\%) and the Russian Federation (62\%), and the lowest ones in Sweden (12\%). It is important to note that in Poland, the percentage of female smokers is high (22\%) compared to the other European countries (Slovakia 14\%, Ukraine 16\%). Higher percentages of women who smoked cigarettes on a daily basis were observed in Greece (39\%) and Austria (36\%). In general, higher number of smoking men compared to smoking women is observed in most European countries [10].

In GATS Poland, smoking prevalence varied among age groups similarly to other studies [11,12]. Our results show that the lowest daily smoking prevalence was recorded among subjects younger than 20 . At the same time, the high rates of smoking among women at the reproductive age in the group between 20 and 40 years where most births are recorded, are alarming. At this age, women potentially are planning pregnancy, are pregnant or are taking care of children. Therefore, high smoking rates in this group may also significantly affect the health of future generations and this group seems to be the target group for antismoking activities.

Regardless of age group, males were more likely to smoke than females in other analyzed categories, including education, place of residence and occupational status. 
Low education is unquestionably the most important risk factor with multivariate odds of smoking in men 2.8 (95\% CI: 2.1-3.9) and women 2.3 (95\% CI: 1.7-3.0). Other studies previously conducted in Poland and European countries have also shown that smoking prevalence increases with the decreasing level of education [13-18]. These findings can be explained by a more profound knowledge on health consequences of smoking and different attitudes to their own health among the people who are well educated, compared to those who are not. It is suggested that higher education may increase awareness of the benefits of healthy lifestyle, and improve individuals' ability to follow health education messages [15]. Higher education usually enhances individual's job opportunities and helps to get more stable, better paid jobs that offer more favorable work conditions as well. On the other hand, smoking is a more frequent mechanism for coping with stress among individuals with lower education [14]. Moreover, higher smoking prevalence among low educated groups is explained by differences in access to, and effectiveness of, cessation treatments [14].

Among women, smoking was directly correlated with increasing urbanization level. Among males, this association was not so clear and strong. We reported highest daily smoking among male residents of cities with 50000 to 200000 inhabitants.

Smoking among rural women in Poland seems to be still less socially acceptable than in large cities. Higher prevalence of smoking among females from large urban settings may reflect response to intensive targeted cigarette advertising campaigns [19]. Moreover, factors related to women's emancipation and their higher spending power is suggested to influence smoking patterns among urban women $[19,20]$. Workforce participation as well as media influence leads to a change in perceived gender roles in society. These circumstances can partly explain the high number of smoking women in cities. On the other hand, women in rural areas are less economically active, more traditionally involved in raising children and occupied with household keeping than those living in large cities. Higher smoking prevalence in urban compared to nonurban areas was similarly found in other previously published studies from developed countries [12,21-23]. Daily smoking was much more prevalent in the group of unemployed men compared with hired employees. Other authors also reported a strong association between cigarette smoking and socio-economic status [17,23-27]. In our study, unemployment did not influence daily smoking among women. The difference in the results for men and women might be explained by the fact that in Poland, there is still a relatively lower proportion of women than men contributing to the labor market compared with more developed countries. As before, in most households, it is the male members that are predominantly responsible for assuring family's subsistence. Recently, the female employment rate in Poland (52.4\%) has remained at one of the lowest levels in Europe. Statistics show an increase in disparities in employment rates by gender in the age group 20-40, the period when women become involved in maternal responsibilities [28]. The disparity in access to employment for women in this age group is also related to the difficulties in combining work and family responsibilities.

It is quite likely that in the group of unemployed women, their partners can take the responsibility of assuring family's subsistence and, therefore, there is no dramatic decline in the financial situation due to female unemployment. However, this topic needs to be explored further.

\section{Study limitations}

Some study limitations need to be highlighted. A potential limitation is the possibility of the recall bias due to self-reported data on tobacco use. There is always the possibility that data about smoking status obtained by questionnaire can be underestimated as the people might not say the truth about their smoking habit. There are a lot of markers or biomarkers of tobacco smoking or ETS exposure (nicotine, 
cotinine, $\mathrm{CO}, \mathrm{SCN}$ ) which can be used for the verification of the information obtained by questionnaire [29]. But selfreported smoking has been found to be an accurate measure in most studies, especially in case of interviewer-administrated questionnaires [30]. Another potential limitation of epidemiological studies is low participation rate. However, response rate in GATS exceeded $65 \%$ of the typical level, or even higher than in other nationwide population-representative questionnaire surveys in Poland [2,5]. Moreover, this level of participation rate meets the GATS sample size requirements and standards of GATS that were reviewed and approved by international experts. The collected data assure population-representative design of the study. The response rate varies between GATS countries. It should be noted that in the GATS have taken part low and middle-income countries differing substantially in terms of economic, social and cultural context, which also affects the respondents' willingness to participate in the research and the availability/access to respondents. For instance, the total survey response rate was $97.7 \%$ in the Russian Federation, 93.7\% in Turkey and $80.1 \%$ in Ukraine. Unfortunately, it is difficult to clearly identify the most important factors that caused these differences. Another limitation is the GATS questionnaire's lack of questions on net household income and more detailed socioeconomic characteristics, allowing for a more in-depth analysis of tobacco use in this context. This requires the incorporation of wide-range socioeconomic and demographic categories in measurement and reporting of tobacco smoking trends. Data on marital status are also missing in GATS questionnaire and these important variables should be taken into consideration in future surveys.

\section{CONCLUSIONS}

Actions to tackle socio-economic inequalities in smoking need to be intensified in Poland. Due to significant differences in smoking prevalence between various sociodemographic groups, future attempts to reduce tobacco smoking should be specific for the targeted subgroups of the populations. The antismoking efforts should be focused on the people with lower educational levels, unemployed men, and residents of large urban settings in particular. As the proportion of daily smoking among women at reproductive age is still high, the tobacco control policies and interventions should also address this population. Tobacco control measures, including those proposed by the WHO MPOWER package, have the strong, proven potential to reduce overall smoking prevalence, and at the same time achieve the reductions among lower socio-economic groups [10,31,32]. These include smoke-free policies, banning of tobacco advertisements, raising tobacco taxes, cessation programs, and warnings on health effects of smoking (including warning labels on cigarette packs) and mass media campaigns [31,32]. Unfortunately, in Poland, some of these tobacco control measures have not been fully implemented [4]. Therefore, there is still a considerable potential for further development and implementation of effective strategies aimed at reducing tobacco use among handicapped social groups. It is crucial to create a supportive environment for lower socio-economic groups in Poland by broader policies engaging multiple sectors: finance, education, industry, labor, environment or trade, and strengthen tobacco control measures not only at national but also at local levels.

\section{ACKNOWLEDGEMENTS}

We would like to thank the representatives of the Global Adult Tobacco Survey (GATS) Scientific Committee (Poland) including: Professor Witold Zatoński (Cancer Center and Institute of Oncology, Warszawa), Professor Bolesław Samoliński (Medical University of Warsaw), Dr. Przemysław Biliński (Chief Sanitary Inspector, Warszawa), and members of the Technical and Survey Staff Team as well as our Partners from the World Health Organization, Centers for Disease Control and Prevention (Dr. Samira Asma, Dr. Krishna Mohan Palipudi), CDC Foundation, Johns Hopkins Bloomberg School of Public Health and the RTI International for their contribution and support. 


\section{REFERENCES}

1. Bogdanovica I, Godfrey F, McNeill A, Britton J. Smoking prevalence in the European Union: a comparison of national and transnational prevalence survey methods and results. Tob Control 2011;20(1):e4. DOI: 10.1136/tc.2010.036103.

2. Polakowska M, Piotrowski W, Tykarski A, Drygas W, Wyrzykowski B, Pająk A, et al. Addiction to tobacco smoking in the Polish population. Results of the WOBASZ program. Kardiol Pol 2005;63(Suppl 4):626-31 [in Polish].

3. West R, Zatonski W, Przewozniak K, Jarvis MJ. Can we trust national smoking prevalence figures? Discrepancies between biochemically assessed and self-reported smoking rates in three countries. Cancer Epidemiol Biomarkers Prev 2007;16(4):820-2.

4. World Health Organization (WHO). The current status of the tobacco epidemic in Poland. Copenhagen: WHO; 2009.

5. Kaleta D, Jegier A. Predictors of inactivity in the working-age population. Int J Occup Med Environ Health 2007;20(2): 175-82.

6. Kaleta D, Kozieł A, Miśkiewicz P. Global Adult Tobacco Survey in Poland - the aim and current experiences. Med Pr 2009;60(3):197-200 [in Polish].

7. Warren CW, Asma S, Lee J, Lee V, Macky J. Global Tobacco Surveillance System. The GTSS Atlas. Atlanta: CDC Foundation; 2009.

8. Warren CW, Lee J, Lea V, Goding A, O'Hara B, Carlberg M. Evolution of the Global Tobacco Surveillance System (GTSS) 1998-2008. Global Health Promotion 2009;16 $\operatorname{Suppl}(2): 4-37$.

9. Ministry of Health of Poland. Global Adult Tobacco Survey. Poland 2009-2010. Warsaw: Ministry of Health; 2010 [cited27 January 2012]. Available from URL: http://www.mz.gov. pl/wwwfiles/ma_struktura/docs/sondaz_tyt_15112010.pdf or www.who.int/tobacco/surveillance/en_tfi_gats.poland-report-2010.pdf [in Polish].

10. World Health Organization (WHO). WHO report on the global tobacco epidemic. Implementing smoke-free environments. Geneva: WHO; 2009.
11. Ali M, Chaix B, Merlo J, Rosvall M, Wamala S, Lindström M. Gender differences in daily smoking prevalence in different age strata: A population-based study in southern Sweden. Scand J Public Health 2009;37(2):146-52.

12. Li FX, Robson PJ, Ashbury FD, Hatcher J, Bryant HE. Smoking Frequency, Prevalence and Trends, and Their Sociodemographic Associations in Alberta, Canada. Can J Public Health 2009;100(6):453-8.

13. Cavelaars AEJM, Kunst AE, Geurts JJM, Crialesi R, Grötvedt L, Helmert U, et al. Educational differences in smoking: international comparison. BMJ 2000;320:1102-7.

14. Gilman SE, Martin LT, Abrams DB, Kawachi I, Kubzansky L, Loucks EB, et al. Educational attainment and cigarette smoking: a causal association? Int J Epidemiol 2008;37: 615-24.

15. Kaleta D, Polańska K, Jegier A. Smoking predictors among economically active individuals. Int J Occup Med Environ Health 2007;20(4):357-63.

16. Scarinci IC, Robinson LA, Alfano CM, Zbikowski SM, Klesges RC. The relationship between socioeconomic status, ethnicity, and cigarette smoking in urban adolescents. Prev Med 2002;34:171-8.

17. Schaap MM, Van Agt HM, Kunst AE. Identification of socioeconomic groups at increased risk for smoking in European countries: Looking beyond educational level. Nicotine Tob Res 2008;10:359-69. DOI: 10.1080/14622200701825

18. World Health Organization (WHO). Systematic review of the link between tobacco and the poverty. Geneva: WHO; 2011.

19. Schaap MM, Kunst AE, Leinsalu M, Regidor E, Espelt A, Ekholm O. Female ever-smoking, education, emancipation and economic development in 19 European countries. Soc Sci Med 2009;68:1271-8.

20. Kaleta D, Usidame B, Polańska K. Tobacco advertisements to women: creating an awareness among women. Cent Eur J Public Health 2011;19(2):73-8.

21. Idris BI, Giskes K, Borrell C, Benach J, Costa G, Federico $\mathrm{B}$, et al. Higher smoking prevalence in urban compared to nonurban areas: Time trends in six European countries. Health Place 2007;13(3):702-12. 
22. Völzke H, Neuhauser H, Moebus S, Baumert J, Berger K, Stang A. Urban-rural disparities in smoking behaviour in Germany. BMC Public Health 2006;6:146.

23. Osler M, Holstein B, Avlund K, Damsgaard MT, Rasmussen NK. Socioeconomic position and smoking behaviour in Danish adults. Scand J Public Health 2001;29:32-9.

24. De Vogli R, Santinello M. Unemployment and smoking: does psychosocial stress matter? Tob Control 2005;14:389-95. DOI:10.1136/tc.2004.010611.

25. Huisman M, Lenthe FJV, Giskes K, Kamphuis CB, Brug J, Mackenbach JP. Explaining socio-economic inequalities in daily smoking: a social-ecological approach. Eur J Public Health 2011 Apr 7. [Epub ahead of print]. DOI: 10.1093/ eurpub/ckr039.

26. Laaksonen M, Rahkonen O, Karvonen S, Lahelma E. Socioeconomic status and smoking: Analysing inequalities with multiple indicators. Eur J Public Health 2005;15(3):262-9.

27. Ohlander E, Vikstrom M, Lindstrom M, Sundquist K. Neighborhood non-employment and daily smoking: a population-based study of women and men in Sweden. Eur J Public Health 2006;16(1):78-84.
28. Eurostat - the statistical office of the European Union. Europe in figures. Eurostat yearbook 2010. Luxembourg: Publications Office of the European Union; 2010 [citation date: 28 August 2011]. Available from URL: http:/epp. eurostat.ec.europa.eu/portal/page/portal/publications/eurostat_yearbook.

29. Kentalaa J, Utriainenb P, Pahkalac K, Mattila K. Verification of adolescent self-reported smoking. Addict Behav 2004;29:405-11.

30. Patrick DL, Cheadle A, Thompson DC, Diehr P, Koepsell T, Kinne S. The Validity of Self-Reported Smoking: A Review and Meta-Analysis. Am J Public Health 1994;84:1086-93.

31. Kaleta D, Polańska K, Wojtysiak P, Kozieł A, Kwaśniewska M, Miśkiewicz P, et al. Effective protection from exposure to environmental tobacco smoke in Poland: The World Health Organization perspective. Int J Occup Med Environ Health 2010;23(2):123-31. DOI 10.2478/v10001010-0014-7.

32. Schaap MM, Kunst E. Monitoring of socioeconomic inequalities in smoking: Learning from the experiences of recent scientific studies. Public Health 2009;123:103-9.

This work is available in Open Access model and licensed under a Creative Commons Attribution-NonCommercial 3.0 Poland License - http://creativecommons.org/ licenses/by-nc/3.0/pl/deed.en. 